\title{
SECONDARY POLLEN PRESENTATION, PSYCHOPHILY AND ANEMOCHORY IN Lagascea mollis Cav. (ASTERACEAE)
}

\author{
M. MALLIKARJUNA RAO and ALURI JACOB SOLOMON RAJU* \\ Department of Environmental Sciences, Andhra University, Visakhapatnam 530 003, India
}

Received 19 September 2016/Accepted 12 Oktober 2017

\begin{abstract}
Information on pollination ecology and seed dispersal aspects is essential to understand sexual reproduction in Lagascea mollis Cav. The study was aimed at providing details of pollen presentation system, pollination syndrome, pollinators and seed dispersal mode for L. mollis based mostly on field study. Paper chromatography technique was used for recording sugar and amino acid types in the nectar, since they are important to evaluate the pollination syndrome. The study indicated that L. mollis flowers during August-November. The plant produces synflorescences consisting of several capitula. Each capitulum produces a single disc floret. The plant is protandrous, temporally dioecious and exhibits secondary pollen presentation using brush mechanism to prevent autonomous selfing. The floral characteristics such as having synflorescence, narrow tubular corolla, production of sucrose-rich nectar with essential and non-essential amino acids and pollen charactersistics such as having spherical shape, tri-colpate apertures and strongly spinulose exine suggested that the plant is adapted for insect pollination. The plant is principally psychophilous. Other insects also visited the florets opportunistically and acted as supplementary pollinators. Further, thrips used this plant as breeding and feeding sites; their effect mostly geitonogamy. The fruit is an achene, anemochorous and also anthropochorous. Regeneration occurred from seeds and perennial root stock during rainy season.
\end{abstract}

Keywords: Anemochory, anthropochory, brush mechanism, Lagascea mollis, psychophily, secondary pollen presentation

\section{INTRODUCTION}

Asteraceae is a large cosmopolitan group. Phylogenetically, the family is considered as highly evolved as is substantiated by specialization in the floral and pollination mechanism (Mabberley 2008). Asteraceae is generally acclaimed to be one of the few well-known families among the dicotyledons, when viewed from several standpoints. Many specialists such as taxonomists, biosystematics, chemotaxonomists, cytologists, cytogeneticists, anatomists and synantherologists have been actively playing their investigatory role in the fertile court of Asteraceae, thereby achieving fruitful results. Czarnecka and Denisow (2014) reported that Asteraceae plants show an extreme diversity of breeding systems with many species having a pronounced flexibility in the breeding strategy. Asteraceae are generalists with

\footnotetext{
* Corresponding author: solomonraju@gmail.com
}

flowers adapted to pollination by several insect groups i.e. Hymenoptera, Coleoptera, Diptera and Lepidoptera (Kratochwil et al. 2009).

Approximately 40 genera within the Asteraceae have secondarily aggregated flowering heads called "synflorescences" (Wunderlin 2017). Lagascea is one such genus with synflorescence type of inflorescence. Lagascea mollis Cav. (subfamily Asteroideae; tribe Heliantheae) is often cited by farmers for its ability to control noxious weeds as well as to serve as a feed for animals (Gliessman 2013). L. mollis leaf paste is used to treat cuts and wounds, while its flowers are used for ear complaints (Kumar \& Atul 2010). Despite its ecological and medicinal importance, there is absolutely no information on the reproductive biology of this species to understand the factors contributing to its weedy nature. The present study was aimed to investigate the following objectives: floral structural and functional morphology, anther dehiscence and pollen 
presentation, growth and behavior of style during anthesis, pollination mechanism, pollination, pollinators, sexual system and seed dispersal in Lagascea mollis Cav. This study provide useful information to understand the functionality of pollination and sexual systems in this plant species that enables this plant to grow, survive as isolated individuals or as population in disturbed and undisturbed habitats.

\section{MATERIALS AND METHODS}

\section{Study Area, Flowering Season, Flower Morphology and Inflorescence Flowering Phenology}

Population of Lagascea mollis growing at the foothills of Visakhapatnam $\left(17^{\circ} 42^{\prime} \mathrm{N}\right.$ and $82^{\circ} 18^{\prime}$ E with $45 \mathrm{~m}$ elevation) in the State of Andhra Pradesh, India, were used for the study. Regular field visits were made to record the flowering season. Ten inflorescences which had not initiated flowering were tagged and observed daily to record the flowering duration and the number of flowers produced. Twenty-five fresh florets were used to record the floral characters.

\section{Anthesis and Anther Dehiscence}

Anthesis was initially recorded by observing the marked synflorescences in the field. Later, the observations were repeated 4 times on different days in order to record accurate anthesis schedule. Similarly, the mature buds were followed for recording the time of anther dehiscence. The pollen presentation pattern was also investigated by recording how anthers dehisced and the same was confirmed by observing the anthers under a hand lens having $10 \mathrm{x}$ magnification.

\section{Analysis of Nectar Reward}

The presence of nectar was determined by gently pulling a floret from its calyx and firmly pressing its base against a hard surface. The micropipette was inserted into the floret base to extract nectar for measurement. The average of nectar of all open florets of ten synflorescences was taken as the total volume of nectar/floret and expressed in $\mu \mathrm{L}$. Paper chromatography technique was used for recording sugar and amino acids types present in the nectar.

\section{Pollen Output}

Twenty-five mature but un-dehisced anthers were collected from different plants and placed in a petri dish. Later, each of the 25 collected anthers was taken out and placed on a clean microscope slide $(75 \times 25 \mathrm{~mm})$ and dabbed with a needle in a drop of lactophenol-aniline blue to collect total pollen of the collected anthers. The pollen mass was drawn into a band and the total number of pollen grains was counted under a compound microscope (40x objective, 10x eye piece). This procedure was followed by counting the number of pollen grains in each anther collected. Based on these counts, the mean number of pollen produced per anther was determined. The mean pollen output per anther was multiplied by the number of anthers in the flower for obtaining the mean number of pollen grains per flower. Another set of dehisced anthers was collected in a petri dish and the pollen removed from these anthers was examined under microscope for recording the pollen grain features.

\section{Stigma Receptivity}

The stigma receptivity was observed visually using $\mathrm{H}_{2} \mathrm{O}_{2}$ test. In visual method, the stigma physical state (wet or dry) and the unfolding of its lobes were considered to record the commencement of receptivity; withering of the lobes was taken as loss of receptivity.

\section{Foraging Activity of Insects}

The insect species were observed visually using binoculars to list them out. Their foraging activities were recorded for 10 minutes at each hour for the entire day. Observation duration was 48 hours distributed on four different days. The data were tabulated to record the foraging activity rate at different times of the day and to record the percentage of foraging visits made by each category of insects per day. Simultaneously, the role of these insects in affecting pollination was observed.

\section{Determination of Pollen Carryover Efficiency of Insects}

Ten individuals of each insect species were captured from the florets during their peak 
foraging activity period and brought to the laboratory. These insects were washed with ethyl alcohol. Contents of these insects were stained with aniline-blue on a glass slide and then observed under microscope to count the number of pollen grains present, to record their pollen carryover efficiency and to determine their role on pollination.

\section{Natural Fruit and Seed Set Rates}

A sample of fruited florets from different synflorescences was collected. Based on seed status in each fruited floret, the fruit set was calculated. Seeds were found to be consisted of two types i.e. unfilled or half-filled and completely filled. Using this as a criterion, filled seed set was calculated. Filled seeds were designated as viable ones, while the unfilled or half-filled ones as in-viable ones.

\section{Seed Dispersal and Germination Season}

Twenty synflorescences were tagged and observed to determine the duration of fruit maturation. Seed characteristics were observed to evaluate their mode of dispersal. Field visits were made to record whether the seeds germinated immediately after they were dispersed or not. Further, field studies were carried out to find out whether L. mollis sprouted from perennial root stock and carried out sexual reproduction.

\section{RESULTS AND DISCUSSION}

\section{Phenology}

Information on the phenology of Lagascea mollis is lacking. The present study showed that this plant is an erect much-branched annual herb growing primarily in sunny or slightly shaded waste lands, along roadsides and cultivated lands with well drained moist soils (Fig. 1a). This plant forms patchy population in certain areas where there are no other bushy or shrubby plants. In such localities, the presence of this species is quite distinct and visible even from a distance. Stems are slightly purplish with stipitate glandular hairs which are prominent on young parts. Leaves are petiolate, usually opposite, upper ones are sometimes alternate, ovate-lanceolate, margins serrate, apex acuminate, densely whitish pubescent on both surfaces. The plant appears during June/July with the onset of rainy season and disappears with the onset of winter season. This plant extends its growth, flowering and fruiting almost throughout the year when the soil is adequately wet. Re-growth occurs from underground root stock within the growing season in areas where the plant has well developed underground root stock. Irrespective of the soil moisture status, the plant shows peak flowering during August-November (Fig. 1b). Individual plants produce synflorescences with purple florets. Each plant produces 15-31 long-

Table 1 Anthesis as a function of time in Lagascea mollis

\begin{tabular}{|c|c|c|c|c|c|c|c|c|c|c|c|}
\hline \multirow{2}{*}{$\begin{array}{l}\text { Time } \\
\text { (h) }\end{array}$} & \multicolumn{11}{|c|}{ Number of florets anthesed } \\
\hline & Day 1 & $\%$ & Day 2 & $\%$ & Day 3 & $\%$ & Day 4 & $\%$ & Day 5 & $\%$ & Total \\
\hline 06:00 & - & - & - & - & - & - & - & - & - & - & - \\
\hline 07:00 & 6 & 7 & 5 & 6 & 13 & 15.5 & 8 & 9.5 & 4 & 5 & 43 \\
\hline 08:00 & 6 & 7 & 5 & 6 & 5 & 6 & 6 & 7 & 2 & 2.5 & 28.5 \\
\hline 09:00 & 11 & 13 & 6 & 7 & 3 & 3 & 3 & 4 & 1 & 1.5 & 28.5 \\
\hline $10: 00$ & - & - & - & - & - & - & - & - & - & - & - \\
\hline 11:00 & - & - & - & - & - & - & - & - & - & - & - \\
\hline $12: 00$ & - & - & - & - & - & - & - & - & - & - & - \\
\hline $13: 00$ & - & - & - & - & - & - & - & - & - & - & - \\
\hline $14: 00$ & - & - & - & - & - & - & - & - & - & - & - \\
\hline $15: 00$ & - & - & - & - & - & - & - & - & - & - & - \\
\hline $16: 00$ & - & - & - & - & - & - & - & - & - & - & - \\
\hline $17: 00$ & - & - & - & - & - & - & - & - & - & - & - \\
\hline $18: 00$ & - & - & - & - & - & - & - & - & - & - & - \\
\hline
\end{tabular}



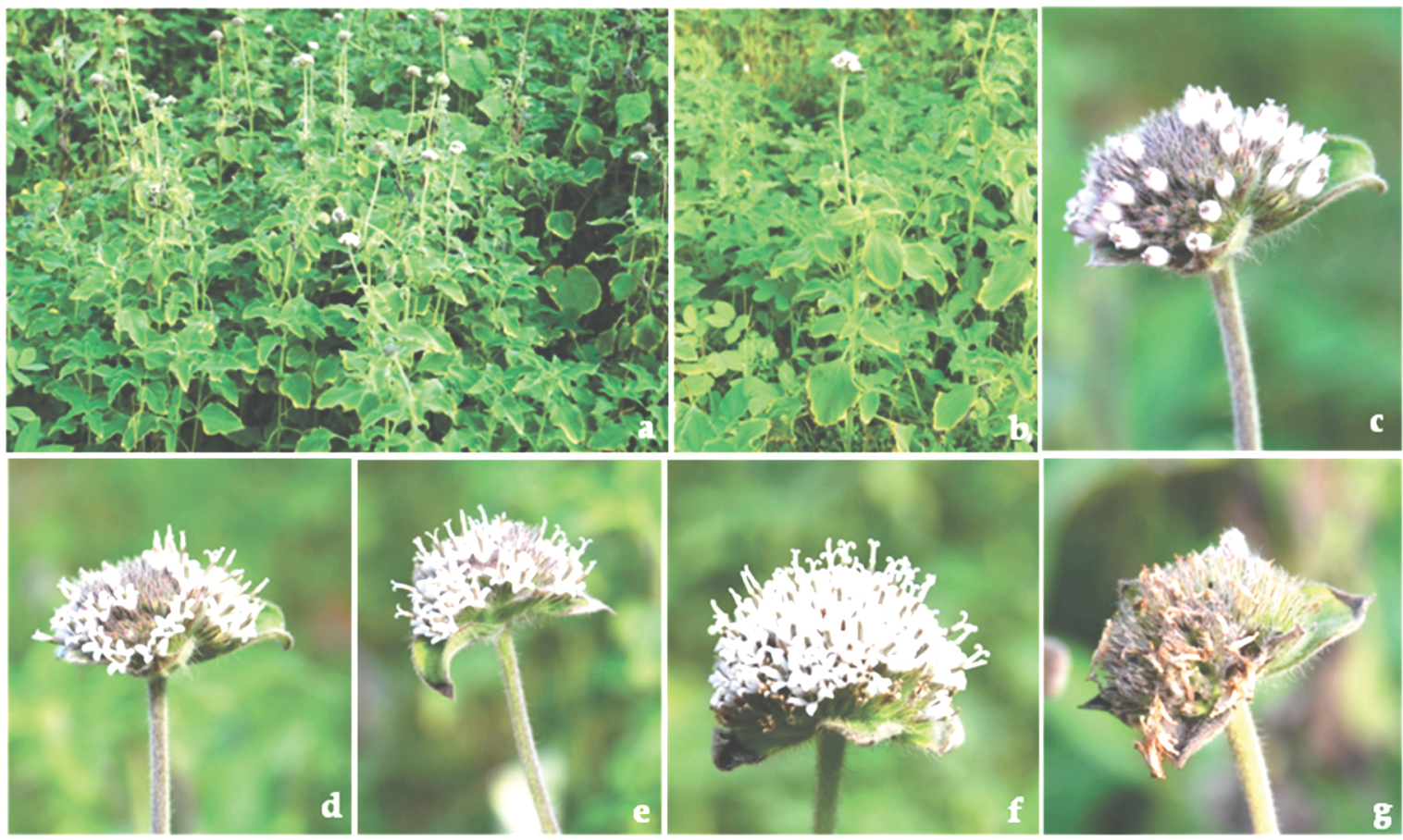

Figure 1 Lagascea mollis: a. Habitat; b. Close-up view of flowering individuals; c-f. Different stages of maturing and anthesing capitulum; g. Spent capitulum

peduncled $(35-52 \mathrm{~cm})$ and disciform glomeruled flat-topped synflorescences terminally. Each synflorescence produces $106.64 \pm 39.70$ uniflowered capitula (13 $\mathrm{mm}$ long, $25 \mathrm{~mm}$ diameter) enclosed by five leaf-like, $4 \mathrm{~mm}$ long tubularcampanulate involucres. All capitula produce only disc florets. The capitula open continually and acropetally over a period of 5 days (Fig. 1c-g). Of the total capitula produced by the synflorescence, $27 \%$ of them open on day $1,19 \%$ on day $2,24.5 \%$ on day $3,20.5 \%$ on day 4 and $9 \%$ on day 5 (Table 1 ).

\section{Flower Morphology}

The floral details are not available from the literature. This study described the floral characteristics together with floral part measurements for $L$. mollis. The plant produces uni-floreted capitula aggregated into a glomeruled, flat-topped synflorescence consisting of only disc florets. The florets are small, tubate (9.4 $\pm 0.9 \mathrm{~mm}$ long, $3.0 \pm 0.5 \mathrm{~mm}$ wide), white with bluish tinge, odorless, actinomorphic, bisexual and nectariferous. The calyx is reduced to leaf-like involucres covered with white silky hairs.
The corolla is tubular $(6.2 \pm 0.4 \mathrm{~mm}$ long, $3 \mathrm{~mm}$ wide) tipped with five glabrous lobes $(1.8 \pm 0.4$ $\mathrm{mm}$ long, $1.2 \pm 0.4 \mathrm{~mm}$ wide). Stamens are five (6.1 $\pm 0.7 \mathrm{~mm}$ long, $1.8 \pm 0.4 \mathrm{~mm}$ wide), white, epipetalous and display syngenesious condition (Fig. 2e); the anthers are $2.6 \mathrm{~mm}$ long, $1.5 \mathrm{~mm}$ wide, dark brown, dithecous and apex appendiculate. The anthers are positioned along the sinuses of the corolla lobes (alternate to the lobes). The anther filaments are free from the corolla just above the tube and the two thecae (pollen sacs) of each stamen are connate with the thecae of adjacent stamens producing a tube that surrounds the style. Pollen is shed to the interior of this tube (introrse dehiscence). The ovary is green ( $3.1 \pm 0.3 \mathrm{~mm}$ long, $1 \mathrm{~mm}$ wide), oblong, hairy, bicarpellary, unilocular with a single ovule on basal placentation (Fig. $2 \mathrm{j}, \mathrm{k}$ ). The style is $5.4 \pm$ $0.5 \mathrm{~mm}$ long and is terminated into 2 externally hairy stylar arms. A nectariferous disc is present at the base of style inside the corolla tube. The style with its stylar branches extends beyond the height of anthers; the stylar branches diverge exposing the inner stigmatic surfaces and curve inwards over-arching the florets (Fig. 2g-i). 


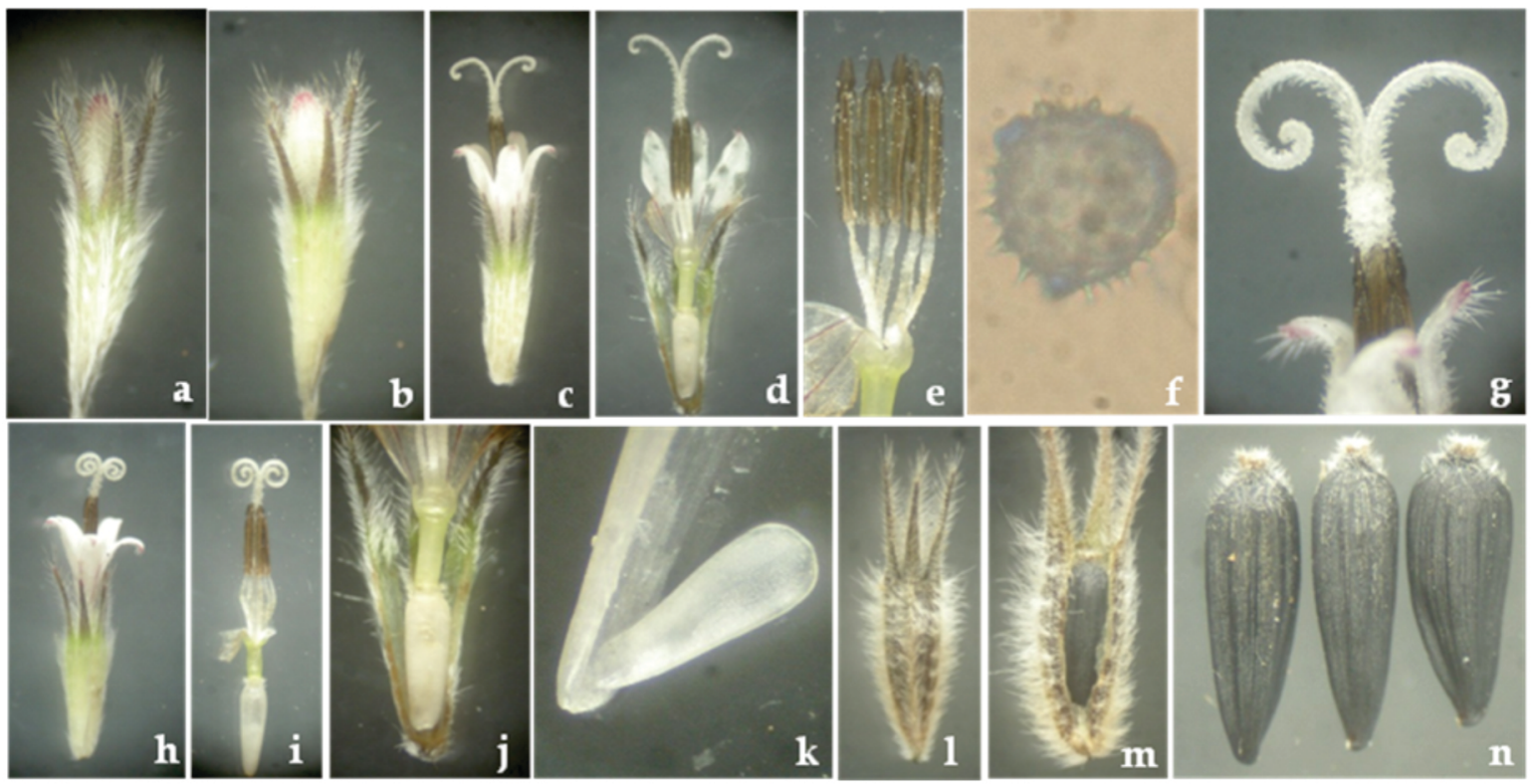

Figure 2 Lagascea mollis: a-d. Disc florets; e. Different stages of anthesis; f. Syngenecious anthers; g-i. Pollen grain; j. Stylar arms exposing the inner receptive stigmatic region; k. Ovary; l. Ovule; m. Fruit; n. Seeds

\section{Floral Biology}

The disc florets opened during early morning between 07.00 and 09.00 hours on clear sunny days (Table 10). The flowers opened completely on sunny days; whereas they were partially opened on rainy days. Individual disc florets took about 3 hours to open from mature bud phase (Fig. 2a-d). Individual synflorescences produced at the terminal part of the erect branches were more conspicuous and therefore, acted as units of attraction to foragers. Furthermore, their anthesis was over in a period of five days and therefore, presentation of fresh and aged florets for more than ten days enhanced attraction to foragers. Each synflorescence consisting of several disc florets enabled pollinator insects to reduce flight time, search time. Therefore, each visit paid by insects was energetically rewarding. The anthers were dehisced by longitudinal slits during mature bud phase indicating that the florets are protandrous. At mature bud stage, the style with its aligned stylar arms lied below the anthers. During and immediately after anthesis, the style grew, elongated and passed through the tube formed by the fused anthers brushing the pollen by the outside stylar hairs. At this stage, the inner stigmatic surfaces were un-receptive and not exposed, the functional situation of which prevented the occurrence of autogamy. Such a form of pollen presentation is referred to as "secondary pollen presentation mechanism" which ensures the pollen availability to insects visiting the capitula on daily basis. The style with its aligned branches gradually diverged in the early hours of the $2^{\text {nd }}$ day; then the inner stigmatic surfaced to attain receptivity and remained so until the end of that day. The stylar arms curved inwards toward the center of the floret, completely exposing the receptive stigmatic surfaces. The pollen grains were creamy white, spherical to rounded, tricolpate, strongly spinulose having size of $26.52 \pm 4.12 \mu \mathrm{m}$ (Fig. 2f). The pollen output per anther was $988 \pm 93.32$ and per flower was 4,940. The pollen-ovule ratio was 4,940: 1. A disc floret produced 1.6 $\mu \mathrm{L}$ of nectar which rose up as it accumulated in the floret due to narrow corolla tube. The sugar types found in the nectar included sucrose and glucose with the first one as dominant. The nectar contained all tested essential and non-essential amino acids. Among essential amino acids, arginine, histidine, methionine and threonine were dominant. Among non-essential amino acids, cystine and hydroxyproline were present in traces, while all others were present in significant levels with same level of occurrence. The disc florets withered away after three days. After the initiation of fruit formation, the withered petals and stamens gradually fell off. 


\section{Pollination Mechanism}

In Asteraceae, secondary pollen presentation system is an important characteristic. It has been considered to be a strategy to improve accuracy in pollen removal and deposition in order to enhance male and female fitness (Erbar \& Leins 2015). In the present study, L. mollis is protandrous. The pollen shed from the anthers was brushed by the sterile hairs (sweeping hairs) from the tip down to the position below the branching of style in the bud stage when the style branches were joined and inner stigmatic surfaces were not receptive. This type of pollen presentation by sweeping hairs is the characteristic of brush mechanism (Torres \& Galetto 2007). As the style grew out of the anther tube, the outer sweeping hairs of the style arms presented pollen for pollination. The receptive papillate stigmatic surface was hidden between the two appressed style arms, preventing self pollination. After the pollen presentation, during the functionally female phase of the floret which occurred on day 2, the style arms separated partially exposing the receptive papillae for the receipt of pollen. The style arms served as secondary pollen presenters in the staminate phase and exposed receptive stigmatic surfaces for pollen during pistillate phase. This type of active pollen presentation was typical of disc florets of
Asteraceae. From day four onwards the florets entered the senescence stage. The secondary pollen presentation system functional in L. mollis appeared to be evolved to enhance the efficiency and accuracy of pollen exportation and/or pollen reception, thus increasing male and/or female fitness of the plant (Erbar \& Leins 2015).

\section{Foraging Activity and Pollination Syndrome}

In L. mollis, the capitula were foraged by bees, wasps, flies and butterflies (Table 2; Fig. 3,4). Of these insects, butterflies made $52 \%$, bees $40 \%$, wasps $6 \%$ and flies $2 \%$ of total foraging visits. The butterflies foraged during 08.00-17.00 hours with peak foraging activity during 09.00-11.00 hours while all other insects during 08.00-15.00 hours with peak foraging activity during 09.0012,00 hours (Fig. 5,6), coinciding well with the standing crop of nectar during that period. Body washings of insects collected from the florets during peak foraging period revealed that the insects carried pollen in amount ranging from 6 to 214 (Table 3).

Lakshmi and Solomon Raju (2011) described the floral characters that conform to butterflypollination. Kost (2015) explained the chemical communication between flowers and insects through nectar chemistry. Our present study

Table 2 List of insect foragers on Lagascea mollis

\begin{tabular}{|c|c|c|c|c|c|}
\hline Order & Family & Genus & Species & Common name & Forage sought \\
\hline \multirow[t]{10}{*}{ Hymenoptera } & \multirow[t]{4}{*}{ Apidae } & Apis & cerana $\mathrm{F}$ & Indian Honey Bee & Pollen + Nectar \\
\hline & & Apis & florea $\mathrm{F}$. & Dwarf Honey Bee & Pollen + Nectar \\
\hline & & Ceratina & sp. & Small Carpenter Bee & Pollen + Nectar \\
\hline & & Ceratina & smaragdula $\mathrm{F}$. & Small Carpenter Bee & Pollen + Nectar \\
\hline & \multirow[t]{2}{*}{ Anthophoridae } & Xylocopa & latipes L. & Large Carpenter Bee & Nectar \\
\hline & & Anthophora & bicincta $\mathrm{F}$. & Blue Banded Bee & Pollen + Nectar \\
\hline & \multirow[t]{2}{*}{ Halictidae } & Nomia & sp. & Alkali Bee & Pollen + Nectar \\
\hline & & Lasioglossum & sp. & Sweat Bee & Pollen + Nectar \\
\hline & Scoliidae & Scolia & quadripustulata $\mathrm{F}$. & Blue Winged Wasp & Nectar \\
\hline & Eumenidae & Eumenes & petiolata $\mathrm{F}$ & Potter Wasp & Nectar \\
\hline Diptera & Sarcophagidae & Sarcophaga & sp. & Flesh Fly & Nectar \\
\hline \multirow[t]{12}{*}{ Lepidoptera } & \multirow[t]{2}{*}{ Pieridae } & Catopsilia & pyranthe L. & Mottled Emigrant & Nectar \\
\hline & & Colotis & etrida Boisduval & Small Orange Tip & Nectar \\
\hline & \multirow[t]{6}{*}{ Nymphalidae } & Acraea & violae $\mathrm{F}$. & Tawny Coaster & Nectar \\
\hline & & Junonia & lemonias L. & Lemon Pansy & Nectar \\
\hline & & Precis & iphita Cramer & Chocolate Pansy & Nectar \\
\hline & & Danaus & chrysippus L. & Plain Tiger & Nectar \\
\hline & & Danaus & genutia Cramer & Striped Tiger & Nectar \\
\hline & & Byblia & ilithyia Drury & Joker & Nectar \\
\hline & \multirow[t]{4}{*}{ Lycaenidae } & Castalius & rosimon $\mathrm{F}$ & Common Pierrot & Nectar \\
\hline & & Zizeeria & karsandra Moore & Dark Grass Blue & Nectar \\
\hline & & Azanus & jesous Guerin & African Babul Blue & Nectar \\
\hline & & Spindasis & vulcanus $\mathrm{F}$. & Common Silver Line & Nectar \\
\hline
\end{tabular}



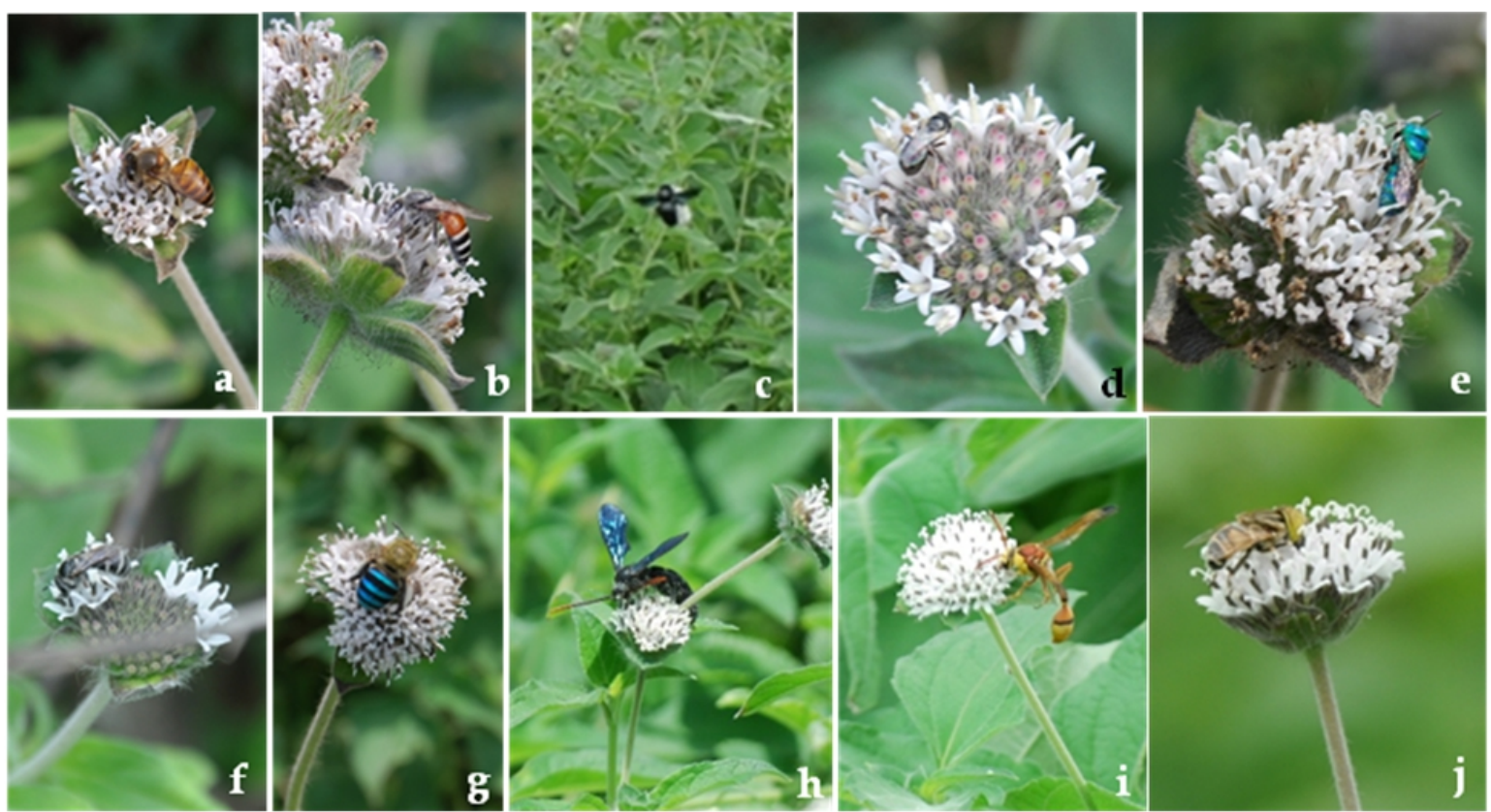

Figure 3 Lagascea mollis: a. Apis cerana; b. Apis florea; c. Xylocopa latipes; d. Ceratina sp.; e. Ceratina smaragdula; f. Nomia sp.; g. Anthophora bicincta; h. Scolia quadripustulata; i. Eumenespetiolata; j. Sarcophaga sp.
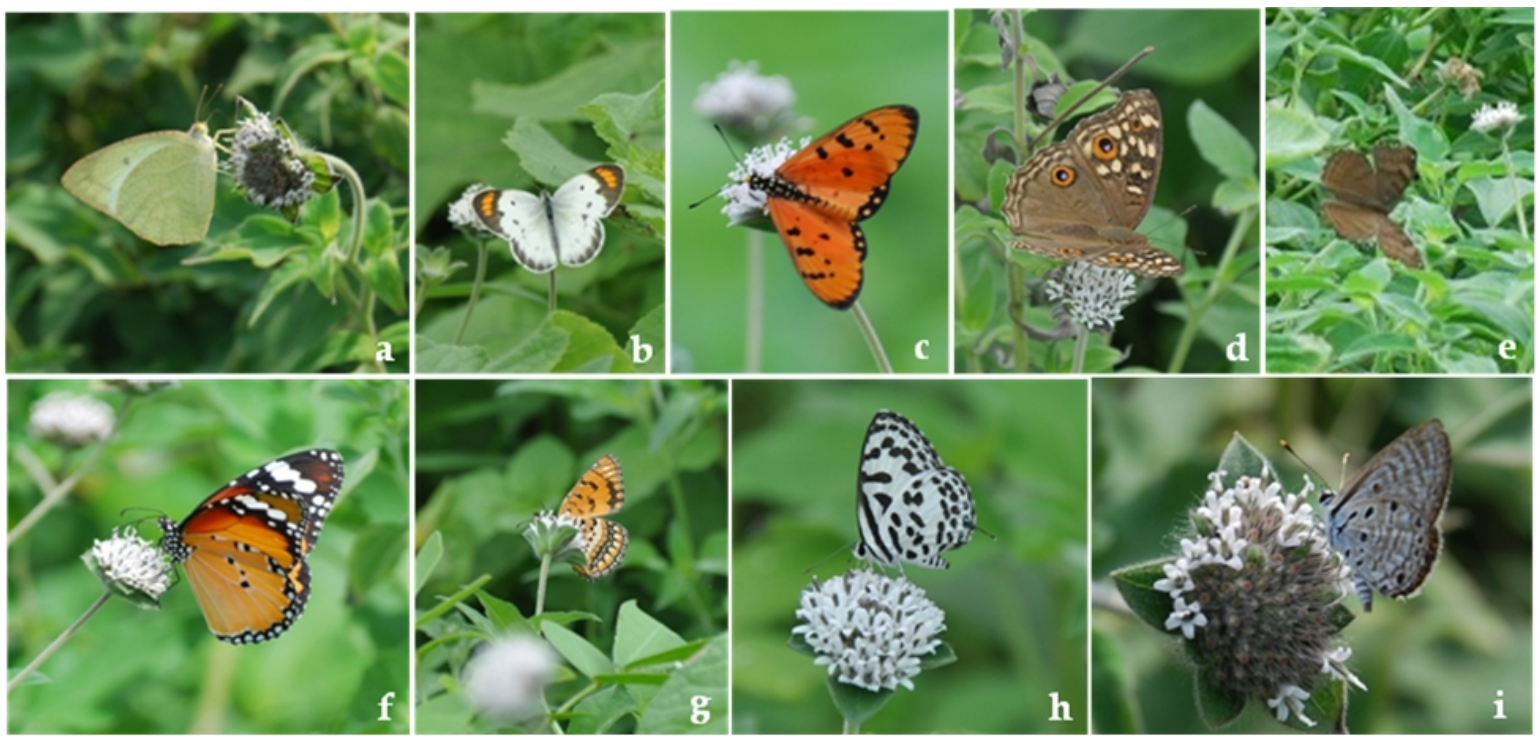

Figure 4 Lagascea mollis: a. \& b. Pierids: a. Catopsilia pyranthe; b. Colotis etrida; c-g. Nymphalids: c. Acraea violae; d. Junonia lemonias; e. Precis i力hita; f. Danaus chrysippus; g. Byblia ilithyia; h. \& i. Lycaenids: h. Castalius rosimon; i. Azanus jesous

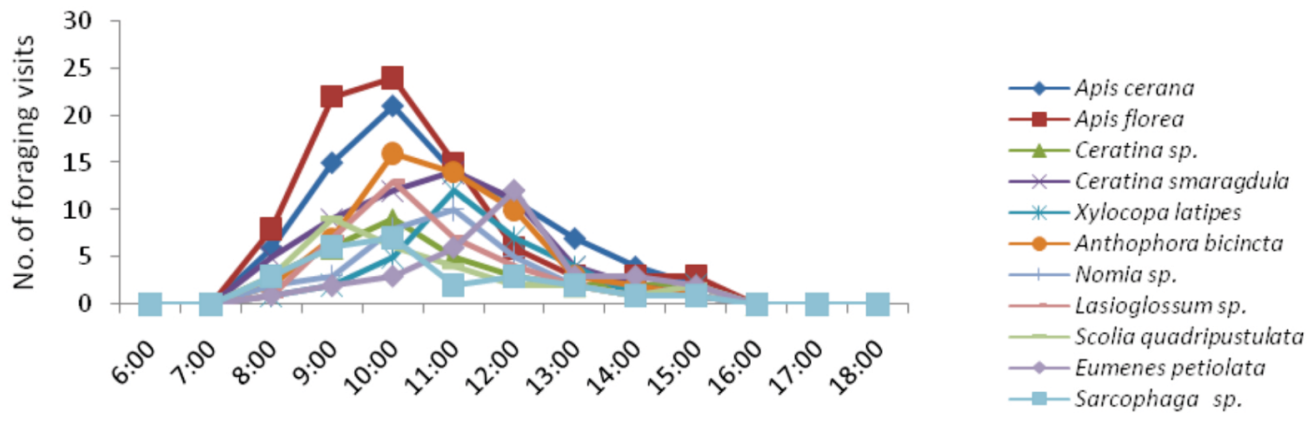

Time (h)

Figure 5 Hourly foraging activity of bees, wasps and flies on Lagascea mollis 

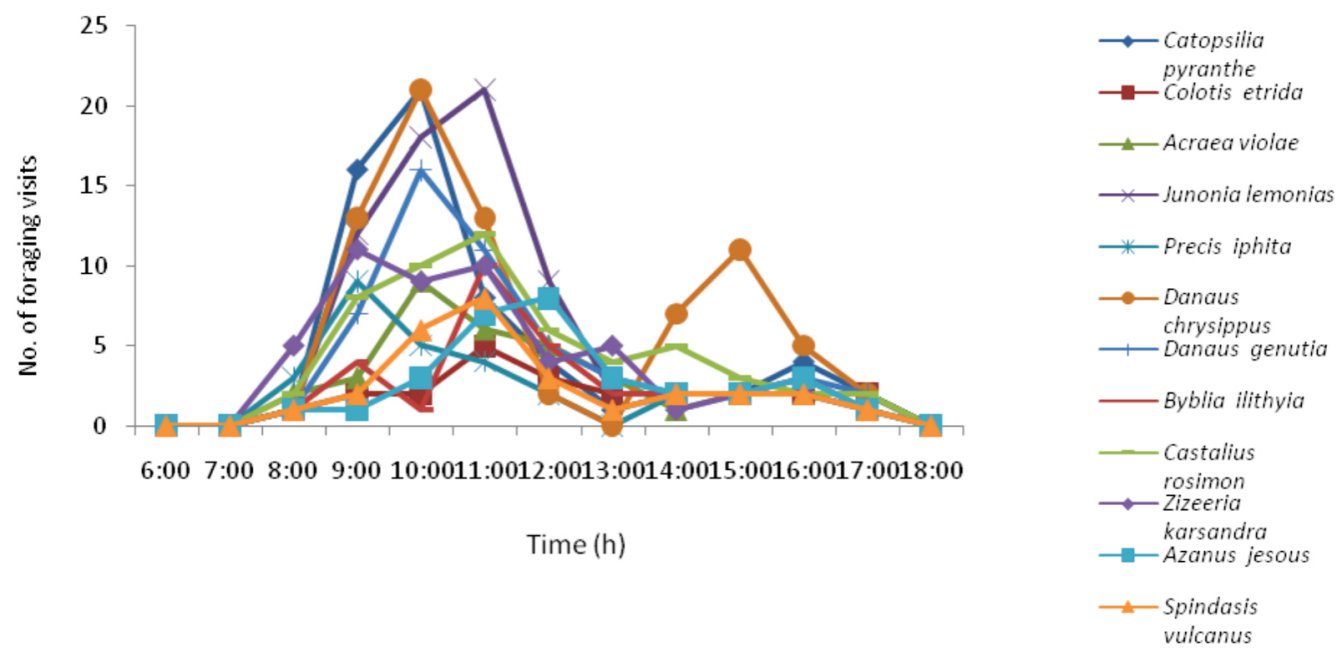

Figure 6 Hourly foraging activity of butterflies on Lagascea mollis

Table 3 Pollen recorded in the body washings of butterflies on Lagascea mollis

\begin{tabular}{|c|c|c|c|c|}
\hline \multirow{2}{*}{ Insect species } & \multirow{2}{*}{$\begin{array}{l}\text { Sample size } \\
\text { (N) }\end{array}$} & \multicolumn{3}{|c|}{ Number of pollen grains } \\
\hline & & Range & Mean & SD \\
\hline \multicolumn{5}{|l|}{ Bees } \\
\hline Apis cerana & 10 & $73-214$ & 139.6 & 35.17 \\
\hline Apis florea & 10 & $56-182$ & 121.1 & 29.35 \\
\hline Ceratina sp. & 10 & $29-60$ & 46.8 & 8.29 \\
\hline Ceratina smaragdula & 10 & $37-95$ & 68.8 & 16.32 \\
\hline Xylocopa latipes & 10 & $22-64$ & 42.4 & 10.29 \\
\hline Anthophora bicincta & 10 & $41-92$ & 69.4 & 12.24 \\
\hline Nomia sp. & 10 & $24-56$ & 44.7 & 8.26 \\
\hline Lasioglossum sp. & 10 & $19-63$ & 42.9 & 10.73 \\
\hline \multicolumn{5}{|l|}{ Wasps } \\
\hline Scolia quadripustulata & 10 & $12-35$ & 23.8 & 5.65 \\
\hline Eumenes petiolata & 10 & $15-44$ & 32.8 & 7.55 \\
\hline Sarcophaga sp. & 10 & $9-31$ & 21.5 & 5.91 \\
\hline \multicolumn{5}{|l|}{ Butterflies } \\
\hline Catopsilia pyranthe & 10 & $24-62$ & 46.4 & 10.23 \\
\hline Colotis etrida & 10 & $12-44$ & 26.7 & 7.98 \\
\hline Acraea violae & 10 & $18-53$ & 30.9 & 8.79 \\
\hline Junonia lemonias & 10 & $20-57$ & 40.3 & 9.52 \\
\hline Precis iphita & 10 & $16-48$ & 30.1 & 7.85 \\
\hline Danaus chrysippus & 10 & $26-64$ & 39.7 & 9.94 \\
\hline Danaus genutia & 10 & $12-37$ & 25.7 & 6.23 \\
\hline Byblia ilithyia & 10 & $14-50$ & 28.9 & 10.64 \\
\hline Castalius rosimon & 10 & $11-38$ & 24.5 & 6.75 \\
\hline Zizeeria karsandra & 10 & $8-30$ & 20.6 & 5.37 \\
\hline Aranus jesous & 10 & $10-36$ & 21.5 & 6.81 \\
\hline Spindasis vulcanus & 10 & $6-29$ & 19.5 & 7.50 \\
\hline
\end{tabular}

showed that in L. mollis, the nectar with sucrosedominance containing essential and non-essential amino acids were particular adaptations for psychophily. The synflorescences principally attracted pierid, nymphalid and lycaenid butterflies. The nymphalid and lycaenid butterflies were more speciose and they were important visitors. In their actions, their proboscis gained contact with the stigmatic region exposed by the stylar arms, sweeping hairs 
and the dehisced anthers positioned within the corolla tube. As a result, self or cross-pollination occurred. Self pollination occurred only through geitonogamy due to the occurrence of staminate and pistillate phase of florets at plant level. The pollen carried on their proboscis and forehead parts was sufficient to pollinate individual disc florets because the individual disc florets produced only one ovule per floret. The consistent foraging activity of butterflies observed on L. mollis suggested that the butterflies used this plant as a major nectar source. Therefore, L. mollis is principally psychophilous.

Cherian (2010) mentioned that L. mollis is an important pollen source for Apis dorsata. In this study, L. mollis was pollinated by Xylocopa bees as exclusive nectar collectors, by other bees mostly as pollen collectors, by the occasional foragers, wasps and flies as nectar collectors. All these insects carried pollen on their body and transfered pollen to synflorescences of the same or different plants affecting both geitonogamy and xenogamy. L. mollis was also used by thrips as breeding and feeding sites. Feeding activity during and after anthesis resulted mostly in geitonogamy. Their nectar feeding activity promoted cross-pollination by driving the insects to make multiple visits to the same or different plants in quest of nectar. Therefore, L. mollis is entomophilous in general, but psychophilous in particular.

\section{Fruiting Ecology and Seed Dispersal}

The fertilized florets produced single-seeded fruits within two weeks. Individual synflorescences produced $95 \pm 31$ fruits and $65 \pm$ 17 seeds (Fig. 2l-n). In open-pollinations, fruit set was $75.55 \%$; in which filled seed set was $84.43 \%$ while the remaining percentage of fruits were unfilled which could be mostly from selfedflowers. The fruit is an obovoid achene; black, 3angled, compressed, weakly ribbed, $4 \mathrm{~mm}$ long and $2 \mathrm{~mm}$ wide, indehiscent and crowned with minute pappus at apex. It is surrounded by connate phyllaries topped by scales. The achenes clothed with connate phyllaries did not become airborne when mature and dry. They fell to the ground in the vicinity of the parental plants at low wind speed and dispersed far away from the parental plants at high wind speed during the days of dry spell within the rainy season. Additionally, connate phyllaries covered by well developed scale-like hairs and carrying achenes were easily attached to clothes. In such situation, humans also serve as seed dispersal agents, the mode of which is referred to as anthropochory.

Seeds exhibited dormancy and germinated only during the next rainy season. They germinated readily in open areas with adequate soil moisture. The seedlings withered away and disappeared if there was a long dry spell during rainy season. Therefore, the seedlings appeared to be constrained to expand its distribution range.

However, the sprouting of the well developed underground root stock to produce new cycle of sexual reproduction in areas where the plant has established a large population over the years is indeed a compensation against the constrains experienced by the plant through seed mode of reproduction.

\section{CONCLUSIONS}

Lagascea mollis is a herbaceous seasonal bloomer. It produces synflorescences consisting of several capitula, each with one disc floret. It exhibits secondary pollen presentation mechanism functional through brush mechanism to avoid autonomous selfing, minimize geitonogamy and maximize xenogamy. It is temporally dioecious, self-compatible and selfpollinating through geitonogamy and crosspollinating through xenogamy. The plant is entomophilous, but principally psychophilous. Anemochory and anthropochory are functional modes of seed dispersal. Seeds are dormant and germinate only during rainy season. In certain areas, perennial root stock sprouts and produces new growth and carries out sexual reproduction.

\section{ACKNOWLEDGMENTS}

We thank Andhra University, Visakhapatnam, India, for providing physical facilities to carry out this research work. We also thank Dr K. Venkata Ramana, DST-SERB Young Scientist, Department of Botany, Andhra University, Visakhapatnam, for assistance during field work. 


\section{REFERENCES}

Cherian KJ. 2010. Pollen analysis of Apis dorsata honey collected from the Wardha, Maharashtra. ESSENCE 1:77-80.

Czarnecka B, Denisow B. 2014. Floral biology of Senecio macrophyllus M. Bieb. (Asteraceae), a rare Central European steppe plant. Acta Soc Bot Pol 83:17-27.

Erbar C, Leins P. 2015. Diversity of styles and mechanisms of secondary pollen presentation in basal Asteraceae: new insights in phylogeny and function. Flora 217:109-30.

Gliessman SR. 2013. Applied ecology and agroecology: their role in the design of agricultural projects for the humid tropics. In: Goodland R, editor. Race to save the tropics: ecology and economics for a sustainable future. Washington DC (US): Island Press. p. 33-47.

Kost C. 2015. Chemical communication. In: Jorgensen SE, Fath B, editors. Encyclopedia of Ecology. Oxford (UK): Elsevier Publishers. p. 557-575.
Kratochwil A, Beil, M, Schwabe A. 2009. Complex structure of pollinator-plant interaction-webs: random, nested, with gradients or modules? Apidologie 40:634-50

Kumar SP, Atul S. 2010. Medicinal utilities of weed flora of agriculture field of JNKVV. IJPLS 1:448-50.

Lakshmi PV, Solomon Raju AJ. 2011. Psychophily in Stachytarpheta amaicensis (L.) Vahl. (Verbenaceae). Curr Sci 100:88-95.

Mabberley DJ. 2008. Mabberley's plant-book. A portable dictionary of plants, their classifications and uses. Cambridge (UK): Cambridge University Press.

Torres C, Galetto L. 2007. Style morphological diversity of some Asteraceae species from Argentina: systematic and functional implications. J Plant Res 120:359-64.

Wunderlin RP, Hansen BF, Franck AR, Essig FB. 2017. Atlas of Florida Plants. Tampa (US): Institute for Systematic Botany, University of South Florida. 